\title{
INVENTARISASI FAUNA PADA TAMAN HUTAN KOTA LANGSA UNTUK TUJUAN EKOWISATA
}

\author{
Ramaidani $^{1}$, Vivi Mardina ${ }^{1}$, Mulia Safrida Sari ${ }^{1}$, Kartika Aprilia Putri ${ }^{1}$, Yeni Rimadeni ${ }^{2}$, \\ Meri Andriani ${ }^{3}$ \\ ${ }^{1}$ Program Studi Biologi, Fakultas Teknik, Universitas Samudra, Jl. Prof. Syarief Thayeb, Meurandeh, \\ Langsa, Aceh, Indonesia. 24416 \\ ${ }^{2}$ Poltekkes Kemenkes Aceh, Aceh Besar, Indonesia \\ ${ }^{3}$ Program Studi Teknik Fakultas Teknik, Universitas Samudra, Jl. Prof. Syarief Thayeb, Meurandeh, \\ Langsa, Aceh, Indonesia. 24416 \\ *E-mail koresponden: vmardina@unsam.ac.id
}

\begin{abstract}
ABSTRAK
Penelitian ini bertujuan untuk menginventarisasi jenis fauna di Hutan Lindung Kota Langsa yang berfungsi sebagai ekowisata. Pada penelitian ini metode jelajah dengan pengamatan langsung ke lapangan telah diadopsi dan dianalisis secara deskriptif. Penelitian menghasilkan data yaitu terdapat 21 spesies fauna di Hutan Lindung kota Langsa. Dari 21 spesies fauna yang paling banyak dilindungi di penangkaran tersebut adalah dari ordo Acciptriformes sebanyak 4 spesies, ordo Artiodactyla sebanyak 2 spesies, dan ordo Columbiformes sebanyak 2 spesies. Hasil dari penelitian ini diharapkan dapat memberikan informasi mengenai keanekaraagaman jenis fauna di kawasan Hutan Lindung Kota Langsa yang dimanfaatkan sebagai ekowisata.
\end{abstract}

Kata Kunci: Hutan Lindung, Kota Langsa, Fauna, Spesies

\begin{abstract}
The purpose of this study was to take an inventory and identify the types of fauna in Langsa Forest City Tourism which aims as ecotourism. This study use the cruise method through direct observation to the research location. The qualitative data was describe descriptively. The study reveal that there are 21 species of fauna found in Langsa Forest City Tourism which the most protected animals in captivity composed of 4 species from the order of Acciptriformes, 2 species of Artiodactyla, and 2 species of Columbiformes. The study provided the information about the diversity of fauna species in the Langsa Forest City Tourism which used as ecotourism.
\end{abstract}

Keywords: Langsa Forest City Tourism, Fauna, Species

PENDAHULUAN

Negara Indonesia kaya akan

keanekaragaman (biodiversitas) hayati fauna sehingga dijuluki Mega biodeversitas
Country. Biodeversitas adalah keanekaragaman hayati yang berada di bumi, merujuk pada variasi kehidupan yang meliputi bentuk, jumlah dan karakteristik 
lain yang terdapat pada tingkat genetik, spesies dan komunitas (Wibowo et al., 2021) . Rohman (2019) menyatakan bahwa jenis keanekaragaman atau inventarisasi spesies di daratan Indonesia hanya mencapai $1,3 \%$ daratan bumi, sementara Indonesia terdapat $10 \%$ tumbuhan dunia, $12 \%$ diantaranya mamalia, $16 \%$ adalah reptil dan amfibi serta $17 \%$ bagian dari burung. Makhfirah et al. (2021) dan Wibowo et al. (2021) menyatakan bahwa salah satu kawasan yang memiliki potensi pelestarian fauna adalah kawasan Hutan Lindung Kota Langsa.

Kota Langsa dengan luas area $\pm 10 \mathrm{Ha}$ memiliki potensi hutan alami yang cukup besar yaitu Hutan Mangrove Kuala Langsa (di Gampong Kuala Langsa, Langsa Barat) dan Hutan Lindung di desa Paya Bujok Seulemak, Langsa Baro. Kedua hutan ini berpotensi sebagai kawasan ekowisata (Mardina et al., 2020; Mardina et al., 2019; Safuridar dan Andiny, 2020). Hutan Lindung disebut juga Taman Hutan Kota Langsa, berjarak $\pm 6 \mathrm{Km}$ dari pusat kota Langsa (perjalanan \pm 15 menit dari Kota Langsa). Ekosistem yang ada di Hutan Lindung masih alami dengan tujuan wisata dan edukasi bagi masyarakat, sehingga Pemerintah Kota Langsa melakukan penangkaran flora dan fauna (Wibowo et al., 2021; Makhfirah et al., 2021; Sahara, 2018). Laporan dari Makhfirah et al. (2021) menyatakan terdapat 22 jenis bunga dan 51-58 jenis pohon di Hutan Lindung Kota Langsa (HLKL). Meilani (2017) melaporkan bahwa HLKL memiliki indeks kualitas keanekaragaman kategori sangat baik $(\geq 30$ jenis). Adapun faunanya hanya terdiri dari 3 kelas, 10 spesies di tahun 2017 sehingga sangat penting untuk memperbaharui data inventarisasi jumlah fauna di HLKL. Selain berfungsi sebagai paru-paru kota Langsa, HLKL sangat menarik sebagai tempat penelitian khususnya fauna (Sahara, 2018; Makhfirah et al., 2021) sehingga penelitian ini bermaksud menginventarisasi dan mengidentifikasi jenis fauna pada HLKL sebagai ekowisata daerah.

\section{METODE PENELITIAN}

Dalam penelitian ini menggunakan metode eksplorasi dengan melakukan pengamatan langsung terhadap objek menggunakan metode jelajah (Cruise method) ke lokasi penelitian (HLKL (Rina dan Arico, 2019; Wibowo et al. 2021). Penelitian telah dilaksanakan pada September 2021 dengan peralatan sederhana seperti peta lokasi penelitian, kamera dan ATK. Pada saat pengambilan gambar fauna di Hutan Lindung kota Langsa dilakukan 
secara langsung pada saat menjelajah tempat penangkaran fauna yang melindungi setiap spesies dari fauna tersebut.

Identifikasi spesies fauna dengan melakukan pengamatan morfologi secara langsung dengan melihat bentuk tubuh, warna bulu, bentuk cakang pada reptile dan melihat cara mereka makan maupun berjalan, buku panduan lapangan identifikasi fauna, serta didukung dokumentasi penelitian (Rina dan Arico, 2019). Adapun parameter pengamatan yaitu ciri-ciri morfologi dari setiap fauna tersebut.

\section{HASIL DAN PEMBAHASAN}

Penelitian berhasil mendata 21 spesies fauna di Hutan Lindung kota Langsa. Dari 21 spesies fauna yang paling banyak dilindungi di penangkaran tersebut adalah dari ordo Acciptriformes sebanyak 4 spesies, ordo Artiodactyla sebanyak 2 Spesies, dan ordo Columbiformes sebanyak 2 spesies. Pada penelitian ini juga terdapat beberapa ordo yang lainya yaitu Chelonia, Testudines, Serpenter, Psitaciformes, Galliformes, Ciceniiformes, Primates, Psittaciformes, Perissodacylater, Falconiformes, Squamata, Rodentia, dan Carnivora (Tabel 1).

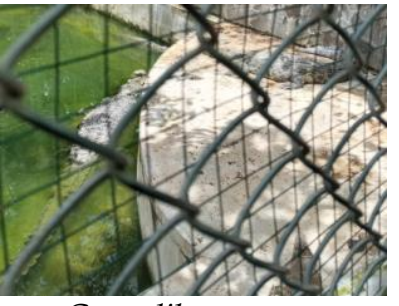

Crocodilus prosus

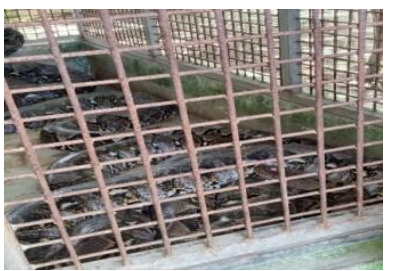

Phyton reticulatus

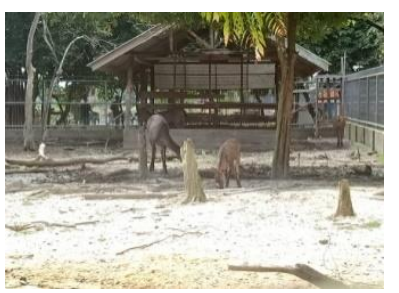

Exsis kuhli

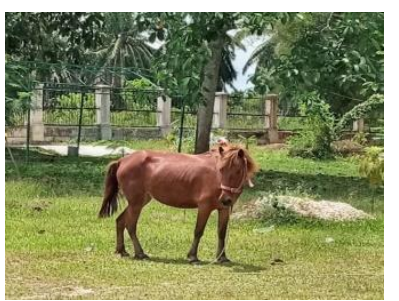

Equus caballus

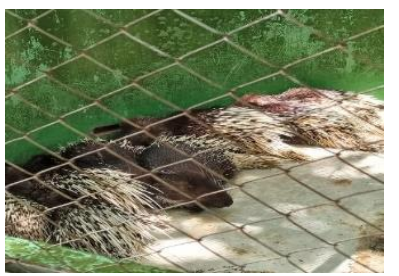

Hystrix javanica

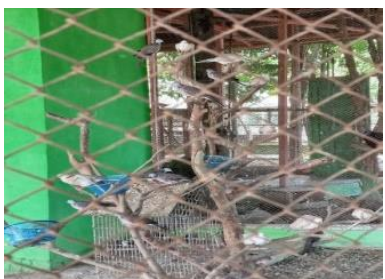

Streptopella chinensis

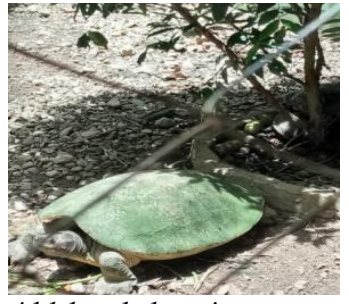

Aldebrachelys gigantean

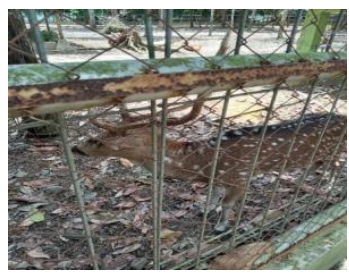

Axis-axis

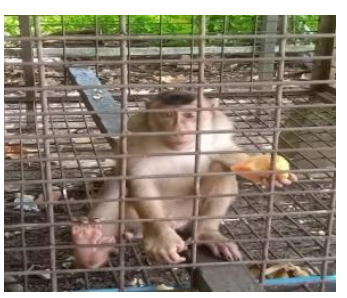

Macaca nomestrina

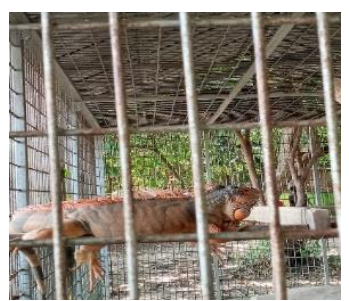

Iguana Antilles

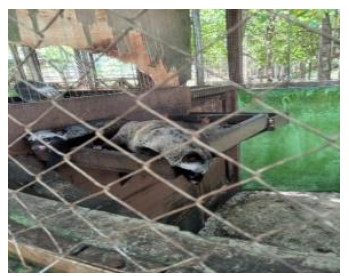

Paradoxurus hermaphrodites

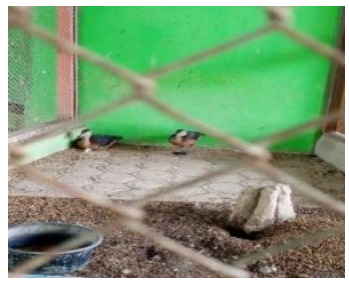

Chinensis dendrocyena 




Ictinaetus malalensis

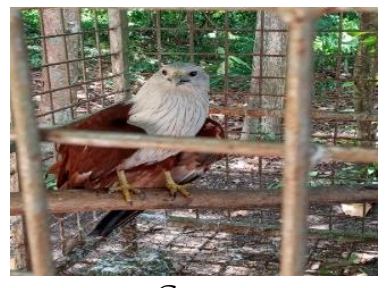

Genera

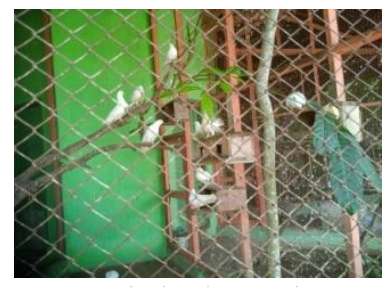

Colmba domestika



Letoptilus javanicus



Haliastur indus

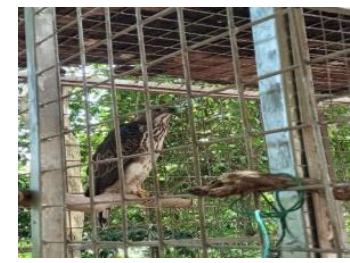

Spilornis cheela

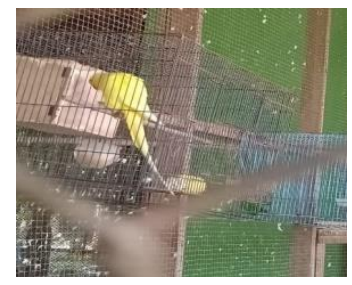

Psitacula krameri



Pavo ctistatus

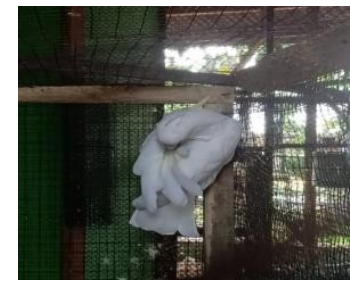

Cacatua moruccensis
Gambar 1. Fauna dalam penangkaran di Hutan Lindung Kota Langsa

\section{Crocodilus prosus}

Buaya, reptil air bertubuh besar memiliki karakteristik fisik yaitu panjang tubuh 2-3 m (umumnya), namun ada juga buaya dengan panjang maksimal $4 \mathrm{~m}$. Gigi tampak jelas, memanjang dengan keeping tabular di kepala yang naik dan menonjol. Terdapat post occipital scutes 2-4 buah yaitu sisik besar di belakang kepala. Adapun sisik kecil di bagian belakang (bawah pangkal ekor, belakang dubur). Jumlah sisik dorsal scutes ada 6 jalur (16-17 baris) dengan sisik perut berjumlah 29-33 baris. Punggung berwarna hijau tua hingga kecokelatan. Gigi buaya berfungsi memegangi, dan mengigit bangsanya.

\section{Aldebrachelys gigantean}

Kura-kura ini memiliki kerapas berwarna coklat kehitaman dengan kubah yang agak tinggi dibandingkan dengan jenis kura-kura yang lain. kura kura Aldebra memiliki kaki yang besar dan kuat, kura-kura tersebut juga memiliki leher yang sedikit panjang. Penyebaran wilayah kura-kura jenis ini di tempat yang berbeda yaitu Pulau Atol Aldabra. Makanan kura-kura ini adalah daun, rumput, dan batang kayu tanaman. Jadi bisa dikatakan kura-kura Aldabra termasuk herbivora, habitat dari kura-kura inia adalah hutan, dataran rendah, padang rumput, rawar bakau, bahkan pantai. Tetapi biasanya kura-kura ini dijumpai di padang rumput karena terdapat banyak sekali makananya. 
Jurnal Jeumpa, 8 (2) Juli-Desembaer 2021

Tabel 1. Iventarisasi fauna di Hutan Lindung Kota Langsa

\begin{tabular}{|c|c|c|c|c|c|c|}
\hline No & Filum & Ordo & Famili & Genus & Spesies & $\begin{array}{l}\text { Nama } \\
\text { Lokal }\end{array}$ \\
\hline 1. & Chordata & Chelonia & Chelodea & Crocodilus & $\begin{array}{l}\text { Crocodilus } \\
\text { prosus }\end{array}$ & Buaya \\
\hline 2. & Chordata & Testudines & Testudinidae & Aldabrachelys & $\begin{array}{l}\text { Aldabrachelys } \\
\text { Gigantean }\end{array}$ & Baneng \\
\hline 3. & Chordata & Sanpentes & Phytonidae & Phyton & $\begin{array}{l}\text { Phyton } \\
\text { Reticulatus }\end{array}$ & $\begin{array}{l}\text { Ular Piton/ } \\
\text { sawah }\end{array}$ \\
\hline 4. & Chordata & Artiodactyla & Carvidae & Axis & Axis-Axis & Rusa tutul \\
\hline 5. & Chordata & Artiodactyla & Carvidae & Exsis & Exsis kuhli & $\begin{array}{l}\text { Rusa } \\
\text { Bawean }\end{array}$ \\
\hline 6. & Chordata & Primates & $\begin{array}{l}\text { Cercopitheci } \\
\text { dae }\end{array}$ & Macaca & $\begin{array}{l}\text { Macaca } \\
\text { nomestrina }\end{array}$ & Beruk \\
\hline 7. & Chordata & $\begin{array}{l}\text { Perissodacyl } \\
\text { ater }\end{array}$ & Equidae & Equus & Equss cabalus & Kuda \\
\hline 8. & Chordata & Squamata & Iguanidae & Iguana & Iguana Antilles & Iguana \\
\hline 9. & Chordata & Rodentia & Hystricidae & Hystrix & $\begin{array}{l}\text { Hystrix } \\
\text { javanica }\end{array}$ & Landak \\
\hline 10. & Chordata & Carnivora & Veveriridae & Paradoxurus & $\begin{array}{l}\text { Paradoxurus } \\
\text { hermaphoditus }\end{array}$ & $\begin{array}{l}\text { Musang } \\
\text { luak }\end{array}$ \\
\hline 11. & Chordata & $\begin{array}{l}\text { Columbifor } \\
\text { mes }\end{array}$ & Columbidae & Strep & $\begin{array}{l}\text { Streptopolia } \\
\text { chinensis }\end{array}$ & $\begin{array}{l}\text { Burung } \\
\text { Balam }\end{array}$ \\
\hline 12. & Chordata & $\begin{array}{l}\text { Anseriforme } \\
\mathrm{s}\end{array}$ & Accipitridae & Dendrocygna & $\begin{array}{l}\text { Chinensis } \\
\text { dendrocyena }\end{array}$ & $\begin{array}{l}\text { Burung } \\
\text { Belibis }\end{array}$ \\
\hline 13. & Chordata & $\begin{array}{l}\text { Acciptrifor } \\
\text { mes }\end{array}$ & Accipitridae & Malayensis & $\begin{array}{l}\text { Ictinaetus } \\
\text { malalensis }\end{array}$ & $\begin{array}{l}\text { Elang } \\
\text { hitam }\end{array}$ \\
\hline 14. & Chordata & $\begin{array}{l}\text { Acciptrifor } \\
\text { mes }\end{array}$ & Accipitridae & Spilornis & $\begin{array}{l}\text { Spilornis } \\
\text { cheela }\end{array}$ & $\begin{array}{l}\text { Elang ular } \\
\text { bido }\end{array}$ \\
\hline 15 & Chordata & $\begin{array}{l}\text { Acciptrifor } \\
\text { mes }\end{array}$ & Accipitridae & Aquila & Genera & Elang \\
\hline 16. & Chordata & $\begin{array}{l}\text { Psittaciform } \\
\text { es }\end{array}$ & Psittacidae & Psitacula & $\begin{array}{l}\text { Psitacula } \\
\text { krameri }\end{array}$ & $\begin{array}{l}\text { Indian } \\
\text { ringneck }\end{array}$ \\
\hline 17. & Chordata & $\begin{array}{l}\text { Columbiafor } \\
\text { mer }\end{array}$ & Columbidae & Columba & $\begin{array}{l}\text { Colmba } \\
\text { domestika }\end{array}$ & $\begin{array}{l}\text { Merpati } \\
\text { kipas }\end{array}$ \\
\hline 18. & Chordata & Galliformes & Phasianidae & Pavo & Pavo ctistatus & $\begin{array}{l}\text { Burung } \\
\text { Kuwoe }\end{array}$ \\
\hline 19. & Chordata & $\begin{array}{l}\text { Ciceniiform } \\
\text { es }\end{array}$ & Ciconiidae & Letoptilus & $\begin{array}{l}\text { Letoptilus } \\
\text { javanicus }\end{array}$ & $\begin{array}{l}\text { Bangau } \\
\text { Tong-tong }\end{array}$ \\
\hline 20. & Chordata & $\begin{array}{l}\text { Phitaciforme } \\
\mathrm{s}\end{array}$ & Psittacidae & Cacatua & $\begin{array}{l}\text { Cacatua } \\
\text { moruccensis }\end{array}$ & $\begin{array}{l}\text { Burung } \\
\text { Kakatua }\end{array}$ \\
\hline 21 & Chordata & $\begin{array}{l}\text { Falconiform } \\
\text { es }\end{array}$ & Accipitridae & Haliastur & $\begin{array}{l}\text { Haliastur } \\
\text { indus }\end{array}$ & $\begin{array}{l}\text { Elang } \\
\text { bondol }\end{array}$ \\
\hline
\end{tabular}




\section{Phyton reticulatus}

Ular piton sawah memiliki pola lingkaran-lingkaran besar berbentuk jala yang tersusun atas warna-warna hitam, kecokelatan, kuning dan putih di sepanjang sisi dorsal tubuhnya. Lubang organ pit terlihat dalam di tiap sisi internasal dengan panjang satu setengah lebarnya. Terdapat sepasang parafrontal besar, supraokular besar dan kadang berbelah, frontal besar, biasanya hanya satu. Memiliki postukular dua sampai tiga. Dua belas hingga empat belas labial atas, empat keping anterior memiliki organ pit, tijuh hingga delapan bersentuh dengan mata, dua atau tiga labial bawah anterior dan lima atau enam labial bawah posterior memiliki organ pit. Sisik 69 hingga, 79 baris, ventral 297 hingga 330, sisik anal tidak berbelah, subcaudal 78 hingga 102. Panjang total dan mencapai 12 m.

\section{Axis-axis}

Rusa tutul merupakan hewan yang memiliki postur lebih ramping dengan ukuran tubuhnya terlihat hanya $91 \mathrm{~cm}$ dengan panjang ekornya yang mencapai 20 $\mathrm{cm}$ hingga $30 \mathrm{~cm}$. adapun berat dari rusa tutul pada umumnya kurang dari $45 \mathrm{~kg}$. adapun rusa jantan memiliki berat badan antara 27 hingga $45 \mathrm{~kg}$ dengan tinggi badan antara 60-100 cm. salah satu yang menjadi khasnya adalah adanya totol-totol yang tersusun seperti garis yang bersebar secara tidak beraturan. Rusa tutul tersebar di beberapa tempat seperti hutan kayu, hutan muda, tepian sungai wilayah india, srilangka, dan ini juga diperkenalkan di Australia.

\section{Exsis kuhli}

Rusa Bawean adalah hewan yang memiliki ukuran tubuh lebih kecil dibanding rusa lain (tinggi $\pm 60-70 \mathrm{~cm}$ dengan $\mathrm{BB} 50$ $60 \mathrm{~kg}$. Bayi rusa betina memiliki BB 1-1,5 $\mathrm{kg}$ dan pada rusa jantan dapat mencapai 2 $\mathrm{kg}$. Rusa ini (panjang tubuh $\pm 20 \mathrm{~cm}$ ) berwarna cokelat kemerahan dengan ekor rusa berwarna cokelat dicampur putih dibagian lipatan dalam. Karakteristik lain Bawean adalah bulu di area mata agak kaku, terdapat lekukan kecil yaitu kelenjar preorbital dengan ukuran 1-2cm, memiliki leher yang panjang sehingga kepala hampir sejajar dengan tubuh bagian belakang jika menoleh. Bentuk telinga runcing (untuk rusa jantan) dan membulat untuk betina. sepasang tanduk yang bercabang tiga hanya dimiliki oelh rusa dewasa jantan. Exsis kuhli merupakan endemik yang terdapat di pulau Bawean (dikawasan Laut Jawa-Indonesia.

\section{Macaca nomestrina}

Beruk merupakan hewan yang masih termasuk kedalam primata. Beruk adalah 
spesies kera berbadan medium. Tubuh beruk berukuran 47-58 cm (BB 3.5-9 kg). Panjang ekor beruk yaitu14-23 cm. Beruk jantan lebih besar ukurannya dibanding beruk betina, dengan otot yang kuat sehingga mmapu memanjat. Terdapat mantel rambut (warna coklat keabu-abuan dan kemerahan dibagian kepala, leher, punggung hingga ekor). Beruk tersebat di daerah beriklim tropis seperti Thailand dan Malaysia. Adapun di Indonesia yaitu di hutan Sumatra, Sulawesi, dan Kalimantan.

\section{Equus caballus}

Kuda adalah salah satu jenis hewan mamalia yang memiliki tinggi badan rerata 160 - $200 \mathrm{~cm}, 4$ kaki yang berotot yang untuk berjalan dan lari cepat, gigi yang cukup panjang, digunakan untuk menguyah makanan, kuda tidak memiliki bagian tulang selangkang, kuda tidak dapat melihat suatu objek tepat dihadapanya (depan) dan juga buta terhadap warna merah, kuda termasuk hewan vertebrata dan invertebrate, memiliki ekor panjang dengan bulu atau rambut panjang di bagian atas kepalanya.

\section{Iguana Antilles}

Iguana adalah hewan reptil yang memiliki lipatan kulit mengaras pada tubuhnya. Lipatan ini tampak sangat jelas dari bagian rahang. Iguana memiliki mata pariental disamping dua mata lainnya, di bagian atas kepala seperti tonggak dengan fungsi untuk mendeteksi hewan predator dan sebagai sensor cahaya. Ada sisik kecil dan sisik bundar besar di bagian pipi (selubung subtimpani), sisik tuberculate di bagian punggung yang berfungsi untuk alat pengelabui musuh seakan iguana tampak besar. Ekor Iguana panjang yang berfungsi sebagai alat keseimbangan tubuhnya, 4 kaki yang dilengkapi 5 jari untuk mencengkeram, berjalan, berpegang. Iguana mampu beradaptasi dengan warna tubuh menyesuaikan diri dengan lingkunganya.

\section{Hystrix javanica}

Landak memiliki bentuk tubuh bulat dan tidak terlalu lincah dalah hal bergerak, memiliki ciri khusus pada tubuhnya yaitu terdapat bulu atau duri sangat tajam. Landak memiliki jumlah gigi sebanyak 36-44 gigi yang tersusun di dalam moncong atau mulutnya, bagian gigi seri lebih panjang dari pada jenis gigi lainya. Landak merupakan hewan nocturnal yang suka aktif dan mencari makanan pada senja dan malam hari, sedangkan pada malam hari barulah mereka banyak menghabiskan waktunya di dalam sarang untuk beristirahat atau tidur. Landak pada indra penglihatanya tidaklah terlalu special dan mereka lebih 
mengandalkan indra penciuman dan juga pendengarannya.

\section{Paradoxurus hermaphrodites}

Musang luak memiliki ukuran tubuh yang berukuran sedang, sisi tubuh berwarna abu kecokelatan, memiliki variasi dan warna tunggal (merah tua atau cokelat ) hingga kehijauan. Umumnya berwarna coklat tua untuk wajah, kaki dan ekor, dan dahi. Pada bawah telinga berwarna keputih-putihan seakan beruban.

\section{Streptopella chinensis}

Burung Balam memiliki ukuran lebih besar pada jantanya dari pada yang betinanya. Balam jantan memiliki bulu sedikit dengan bulu kepala berwarna cerah. Ditinjau dari iris mata, balam jantan terlihat lebuh kecil dan terang dibandingkan dengan betinanya. Kepala jantan lebih tampak berbenjol dinandingkan betina yang terlihat bulat sepenuhnya. Leher jantan memiliki bintik-bintik lebih banyak terang seperti manik-manik dengan lehernya lebih besar dibanding betina.

\section{Chinensis dendrocyena}

Burung Belibis berukuran kecil dibanding spesies burung lainya dengan leher yang tidak terlalu panjang dan kecil. Paruhnya berbentuk pipih (seperti paruh bebek), warna hitam. Bulu dasar berwarna coklat kehitaman. Ujung sayap memiliki bulu putih, ekor pendek, dan ada dua pasang kaki berselaput (hitam). Kaki belibis berselaput yang berfungsi untuk terbang meski belibis sendiri jarang terbang, namun sekali terbang ia mampu terbang jauh.

\section{Ictinaetus malalensis}

Burung Elang Hitam dengan ukuran tubuh sekitar $70 \mathrm{~cm}$ memiliki sepasang sayap, kuku, dan paru baya. Tubuhnya diselubungi bulu pelepah. Warna bulu pada elang tersebut adalah warna hitam pekat. Elang memiliki paruh dan kuku yang kuat dan tajam untuk membawa mangsanya terbang. Elang hitam memiliki daya survival tinggi walaupun pada ketinggian 300 - 2000 dpl. Elang hitam memiliki sayap yang melebar, kokoh dan menjari. Bulu tubuhnya hitam pekat kecuali bagian ekor kecokelatan. Jari kelingking elang hitam pendek dan tidak proporsial.

\section{Spilornis cheela}

Elang Ular Bido merupakan burung berukuran 50-60 $\mathrm{cm}$ dengan sayap huruf $\mathrm{C}$, agak membulat dengan garis tebal putih di bagian tepi. Bagian tepi sayap ekor pendek untuk mengipas. Area sekitaran mata tidak terdapat bulu, namun tubuh dominasi bulu kecokelatan tua / hitam. Area dada dan perut 
berwarna putih dengan kebiasaan terbang soaring dan gliding.

\section{Genera}

Genera atau elang memiliki paruh dan kuku yang kuat dan tajam dengan ukuran \pm $70 \mathrm{~cm}$. Ia mampu membawa mangsanya terbang. Warna bulu elang adalah warna cokelat dan pada kakinya berwarna cokelat kekuningan.

\section{Psitacula krameri}

Burung paruh bengkok dinamakan Ringneck, sangat diminati komunitas paruh bengkok karena adanya bulatan lingkaran seperti kalung dilehernya. Bulatan lingkaran ini hanya ditemukan pada burung jantan dewasa (2-3 tahun). Paruh bengkok tersebar dari benua Afrika hingga Asia.

\section{Colmba domestika}

Burung Merpati memiliki mata yang bersinar terang dan pandangan yang tajam, tidak layu, cepat bereaksi terhadap bendabenda di sekitarnya termasuk cahaya, burung merpati terlihat aktif bergerak dan gesit saat bereaksi dengan lingkungan sekitar ia tidak terlihat diam saja di satu tempat, akan bereaksi jika melihat lawan jenis misalnya salah tingkah, mampu terbang pada ketinggian yang lebih tinggi hingga 77,6 mph dengan kecepatan rata-rata, mampu menempuh jarak sekitar 600-700 mil dan mampu menavigasi arah terbang dan bisa kembali ke rumah atau tempat asalnya saat dilepaskan.

\section{Pavo ctistatus}

Burung Kuau merak memiliki ukuran tubuh hingga $50 \mathrm{~cm}$ dengan ciri khas bintikbintik di tubuhnya. Pada Kuau jantan terdapat jambul hijau metalik, dengan dada dan tenggorokan mengkilap hijau keunguan. Adapun Kuau betina berwarnanya lebih gelap suram (biru). Semua jenis burung kuau pada bagian pipi dan tenggorakan berwarna kuning pucat, kontras dengan bulu lainya. Bagian iris berwarna kuning, paruh hijau gelap, kulit muka gundul dan merah, kaki/ tungkai hitam. Kuau janta memiliki dua taji. Habitat asli Kuau di hutan hujan daratan rendah di Kalimantan.

\section{Letoptilus javanicus}

Bangau Tong-Tong memiliki kepala yang tidak berbulu, sedangkan lehernya ditutupi bulu halus. Mempunyai warna hitam abu-abu dibagian sayapnya selain itu juga memiliki warna putih yang ada pada sekujur badanya da nada juga berwarna hitam. Burung bagau tong-tong ini juga mempunyai tentang sayap yang lebernya mencapai $60 \mathrm{~cm}$. pada saat berdiri tegak, hewan ini tampaknya tidak memiliki kantung leher seperti halnya bagau lain dari 
keluarga yang sama. Bangau tong-tong umumnya akan mendiami daerah daerah yang basah dan tergenang oleh air. Bangau jenis ini tersebar di Malaysia, India Timur, Bangladesh, Kamboja, Thailand, Srilangka, Vietnam, Indonesia dan Laos. Di nusantara kita bangau ini di pulau Jawa, Sumatera, dan Kalimatan

\section{Cacatua moruccensis}

Kakaktua Putih umumnya berwarna putih untuk bulu jambul, lingkar mata. Jantan memiliki mata coklat gelap dan merah coklat untuk betina. Kakaktua ini berukuran besar karena ukuran tubuh sekitar $46 \mathrm{~cm}$, berat tubuh burung ini sekitar 550 gram dengan rentang sayap sekitar 50 sampai $62 \mathrm{~cm}$. kakatua putih memiliki mata cokelat kemerahan atau hitam, paruh dan kaki abu-abu gelap. Ketika jambul diturunkan bulu-bulu melipat kembali di atas kepala dengan rata. Secara umum berwarna putih, termasuk jambul bulu terbang bagian bawah dan ekor bawah kuning, lingkar mata putih, mata cokelat gelap pada jantan dan merah coklat pada betina.

\section{Haliastur indus}

Elang Bondol memiliki ekor pendek, dan membulat jika terbentang. Sayapnya lebar dengan dada, lehar dan kepala berwarna putih. Adapun sisanya berwarna merah bata muda, bagian ujung bulu primer berwarna hitam dan tungkai berwana kuning.

Pada penelitian ini terdapat 21 spesies fauna yang terdapat di Hutan Lindung kota Langsa. Dari 21 spesies fauna yang paling banyak dilindungi di penangkaran tersebut adalah dari ordo Acciptriformes sebanyak 4 spesies, ordo Artiodactyla sebanyak 2 Spesies, dan ordo Columbiformes sebanyak 2 spesies. Pada penelitian ini juga terdapat beberapa ordo yang lainya yaitu Chelonia, Testudines, Serpenter, Psitaciformes, Galliformes, Ciceniiformes, Primates, Psittaciformes, Perissodacylater, Falconiformes, Squamata, Rodentia, dan Carnivora.

Hal ini disebabkan karena Hutan Lindung kota Langsa bukan hanya digunakan sebagai pelindung atau penangkaran satwa fauna saja tetapi digunakan sebagai ekowisata. Di hutan lindung juga banyak hewan yang di hibahkan dari negara-negara tetangga dan kebun binatang seperti Rusa Bawean, Indian Rendchek, Rusa Tutul, Burung kuau. Dengan adanya HLKL bukan hanya dijadikan sebagai paru-paru daerah tetapi juga sebagai tempat penelitian untuk di inventerisasi keanekaragaman hayatinya 
terkhusus jenis faunanya (Sahara, 2018; Makhfirah et al., 2021).

Selain itu HLKL juga memiliki ketinggian yang tepat yaitu 0-26 dpl merupakan daerah tropis yang selalu dipengaruhi oleh angina musim sehingga setiap tahunya ada dua musim yang berbeda yaitu musim hujan dan musim kemarau. Curah hujan rata-rata pertahun berkisar dari 1500 mm-3000 mm, sedangkan suhu udara rata-rata berkisar 28-30 $\mathrm{C}$ dan kelembapan rata-rata $75 \%$. Perbedaan ketinggian tempat menjadi salah satu faktor dijumpainya keanekaragaman satwa (Kartono et al., 2000). Menurut Adhikerana (2013) bahwa semakin tinggi suatu tempat akan berpengaruh terhadap adanya penurunan pada keberadaan keanekaragaman jenis fauna.

Berdasarkan UU No. 41 Tahun 1999, Hutan Lindung sebagai kawasan hutan memiliki fungsi utama yaitu pelindungan/ mengatur tata air sebagai penyangga kehidupan, (2) dapat mencegah terjadinya banjir, erosi, dan intrusi air laut, serta (3) mengendalikan kesuburan tanah. Pemanfaatan Hutan Lindung sebagai hutan kota merupakan suatu terobosan yang sangat baik yang telah dilakukan PEMKO Langsa dan patut dijadikan contoh oleh daerah lain. Selain itu adanya hutan lindung dapat berfungsi keindahan alam yang dapat dinikmati, membuka lapangan kerja dan menambah income daerah. Hutan lindung dapat berfungsi sebagai hutan wisata yang dibina dan dipelihara untuk kepentingan pariwisata dan kebudayaan.

\section{KESIMPULAN}

Pada penelitian ini terdapat 21 spesies fauna yang terdapat di Hutan Lindung kota Langsa. Dari 21 spesies fauna yang paling banyak dilindungi di penangkaran tersebut adalah dari ordo Acciptriformes sebanyak 4 spesies, ordo Artiodactyla sebanyak 2 Spesies, dan ordo Columbiformes sebanyak 2 spesies. Pada penelitian ini juga terdapat beberapa ordo yang lainya yaitu Chelonia, Testudines, Serpenter, Psitaciformes, Galliformes, Ciceniiformes, Primates, Psittaciformes, Perissodacylater, Falconiformes, Squamata, Rodentia, dan Carnivora. Hutan Lindung kota Langsa juga memiliki ketinggian yang tepat yaitu 0-26 dpl merupakan daerah tropis yang selalu dipengaruhi oleh angina musim sehingga setiap tahunya ada dua musim yang berbeda yaitu musim hujan dan musim kemarau. Curah hujan rata-rata pertahun berkisar dari $1500 \mathrm{~mm}-3000 \mathrm{~mm}$, sedangkan suhu udara rata-rata berkisar $28-30{ }^{\circ} \mathrm{C}$ dan kelembapan rata-rata $75 \%$. Perbedaan ketinggian tempat 
menjadi salah satu faktor dijumpainya keanekaragaman satwa (Kartono et al, 2000).

\section{DAFTAR PUSTAKA}

Adhikerana. M. 2013. Identifikasi Keanekaragaman jenis Burung dan Kearifan Tradisional Masyarakat dalam upaya konservasi di pulau Rambut Kepulauan Seribu. Jurnal Formatif, 6(2): 119-124.

Karton, AP., I. Maryanto. 2000. Keragaman Mamalia pada berbagai habitat di Muara Bungo, Jambi. Media Konservasi 7(1):21-28.

Makhfirah N., Utami D , Sena F , Mardina V. , Rimadeni Y.2021. Identifikasi tipe kerusakan pohon di wisata hutan lindung kota langsa. Jurnal Jeumpa, 8 (1): $462-471$.

Mardina V., Fitriani, Muslimah. 2019. Sosialisasi Sistem Penanaman Hidroponik Limbah Tebu di Gampong Sidorejo, Langsa, Aceh. Agrokreatif, Vol 5 (2): 135-140.

Mardina, V., Amri, Y., Harmawan, T. 2020. Pelatihan Teknik Hidroponik untuk Mengatasi Lahan Berkadar Garam Tinggi pada Masyarakat Pesisir Gampong, Kuala Langsa, Aceh. Indonesian Journal of Community Engagement. Vol. 6, No. 1, Maret 2020, Hal. $16-22$.

Meilani, S. 2017. Tingkat pengetahuan masyarakat dan persepsi wisatawan terhadap wisata alam dan komposisi fauna flora di kawasan Hutan Lindung Kota Langsa, Provinsi Aceh. Skripsi,
Jurusan Pendidikan Biologi, FKIP, Universitas Syiuah Kuala.

Pacioni, G. 1981. Guide To Mushrooms. Ed. Gary H. Lincoff. Simon \& Schuster's, Inc. New York.

Polonin, N, 1990. Pengantar Geografi Tumbuhan dan Beberapa Ilmu serumpun,Diterjemahkan Oleh Gembong Tjitrosopomo dari Introduction To Plant Geografi and Same Related Science, Universitas Gajah Mada, Yogyakarta.

Safuridar dan Andiny, P. 2020. Dampak Pengembangan Ekowisata Hutan Mangrove terhadap Sosial dan Ekonomi Masyarakat di Desa Kuala Langsa, Aceh. Jurnal Samudra Ekonomi dan Bisnis. 11(1): 43-52.

Suharna, N. 1993. Keberadaan Basidiomycetes di Cagar Alam Bantimurung, Karaenta dan Sekitarnya, Maros, Sulawesi Selatan. Prosiding Seminar Hasil Litbang SDH 1993. Balitbang Mikrobiologi, Puslitbang Biologi- LIPI. Bogor.

Wibowo SG, Mardina V, Fadhliani. 2021. Eksplorasi dan identifikasi jenis jamur tingkat tinggi di kawasan Hutan Lindung Kota Langsa. Jurnal biological samudra. Vol. 3(1): 1-13. 